\title{
Improving Soil Quality by Using Oil Palm Solid Waste Biochar
}

\author{
Darmawan ${ }^{*}$, Sari Handani ${ }^{2}$ and Ikhsanul Adli ${ }^{2}$ \\ ${ }^{1}$ Faculty of Agriculture, Andalas University; \\ ${ }^{2}$ Master student at Environmental Sciences Department, Andalas University \\ ${ }^{*}$ Coresponding author: darmawan708@gmail.com
}

\begin{abstract}
Solid waste and land degradation are two main problem faced by oil palm plantation in mineral soils. In order to get rid of these difficulties, a field experiment has conducted at re- planting stage of oil palm in PT. Tidar Kerinci Agung plantation. The objective of this study is to examine the potentiality of biochar made from empty bunch of oil palm on soil quality. Fifteen plots of 100 square meters were applied with the dose of 0.0, 2.5, 5.0, 7.5 and $10.0 \mathrm{Mg} /$ ha biochar, respectively. The results show the treatment increase soil organic matter, total pore space, water holding capacity and cation exchange capacity. On the other hand, soil bulk density found decrease significantly along with the treatment. These results indicated that application of biochar might be a better choice for sustainable oil palm plantation in mineral soil.
\end{abstract}

Key words : biochar, land degradation, oil palm, soil quality.

Reference to this paper should be made as follows:

Darmawan, S. Handani, and I. Adli. 2021. Improving soil quality by using oil palm solid waste biochar. Agritropica: Journal of Agricultural Science. 4(1): 20-29 DOI: https://doi.org/10.31186/Jagritropica.4.1.20-29.

\section{INTRODUCTION}

Palm oil is the world's most traded vegetable oil: in August 2012, the share of palm oil (including kernel oil) in world supply was $37.6 \%$ (USDA, 2012). Palm oil is extracted from the fruit of the oil palm tree (Elaeis guineensis); the main products are crude palm oil (CPO) and palm kernel oil (PKO). In terms of land use, the oil palm tree is more efficient than any other oil crop (Corley and Tinker, 2002), and in economic terms palm oil is highly competitive. The value chain of palm oil and its derivatives has a strong degree of vertical integration (World Bank, 2011), and its production costs are relatively low compared to other vegetable oils. It is therefore seen as one of the cheapest and most attractive vegetable oils traded on the world market (Tan et al, 2009; McCarthy and John, 2010).
Palm oil, being a multi-purpose vegetable oil, offers good prospects for further expansion. There is a growing demand from the commercial food and oleo-chemical industries that use oil palm in processed foods, cosmetics, soaps, pharmaceuticals, industrial and agrochemical products, and as a feedstock for bio-diesel. The growing worldwide interest in bio-diesel as an alternative to fossil fuel is expected to lead to the further expansion oil palm plantation (Edward et al, 2010; Koh and Ghazoul, 2008; Germer and Sauerborn, 2008). Oil palm becomes the most important commodity from subsector plantation, which may contribute in Indonesian economy as a whole. Since the price of crude palm oil (CPO) and kernel palm oil (PKO) rise up in global market, Indonesia government encourage to expand oil palm plantation and increase their productivity as well. 
Directorate general of plantation, Department of Agriculture (2014) reported that Indonesia has more than 10.9-million-hectare (ha) oil palm plantation and produce 29.3 million tons CPO, where 281,754 ha of them located in West Sumatra, which produce 1,082,823 tons CPO.

Continuous cropping of annual cash crop, such as oil palm could lead into decreasing in soil organic matter (SOM). The SOM content is a key of soil quality, which indicates the sustainability oil palm farming system. Deterioration of SOM will be resulted in increasing of soil bulk density, decreasing in total pore space and soil permeability, which lowering nutrient uptake efficiency (Reeves, 2007). On the other hand, the CPO production processes created solid waste for more than $60 \%$ of fresh fruit bunch (FFB). This solid waste managed by put them on the surface of the land (as organic mulch). Brady and Weil (2003) stated that about $80 \%$ of decomposable organic matter would convert into $\mathrm{CO}_{2}$ through mineralization process. The better way for organic matter application is using them as biochar.

Addition of biochar to agricultural soils has been proposed as means to improve soil fertility, and mitigate climate change (Lehmann, 2007) through increased soil carbon storage (Lehmann et al, 2006; Fowles, 2007). The amount of oil palm solid waste production in West Sumatra is more than 4.5 million tons per year and tends to increase as oil palm plantation is enlarging in this area. Since application of decomposable organic mater will enhance $\mathrm{CO}_{2}$ emission, this solid waste can be applied as biochar into the soil. The main objective of this study is to examine the capability of empty bunch palm oil biochar to improving land quality.

\section{MATERIALS AND METHODS}

This study was carried out at PT. Tidar Kerinci Agung, the largest oil palm plantation in West Sumatra. The study site located at $001^{\circ} 31^{\prime} 39.2^{\prime \prime}$ S; $101^{\circ} 30^{\prime} 55.6^{\prime \prime}$ E, about $200 \mathrm{~km}$ South of Padang. Eighteen of $15 \mathrm{~m} \times 15 \mathrm{~m}$ plots were established at one month old of oil palm replanting area. The plots were applied with 0.0, 56.0, 112.5, 168.7, 225.0 and 337.5 $\mathrm{kg}$ biochar (equal to 0.0, 2.5, 5.0, 7.5, 10.0 and $15.0 \mathrm{Mg} \mathrm{ha}^{-1}$ ) with three replications. Application of biochar conducted by mixed them manually with topsoil material by using hoe. The first composite and undisturbed (core) soil samples were taken at topsoil $(0-20 \mathrm{~cm})$ and subsoil (20$40 \mathrm{~cm}$ ), one week after treatment. After sampling was continue once a month for 10 months consecutively. The data presented in this paper is for the fourth sample, which had taken at three months after treatment.

\section{Laboratory Analyses}

Total carbon and nitrogen. Airdried soil samples were ground and passed through a $2 \mathrm{~mm}$ sieve and stored in plastic boxes for laboratory analyses. Finely ground soil samples were oven dried at $80^{\circ} \mathrm{C}$ for about 24 hours. Total carbon and nitrogen were determined by dry combustion method (Nelson and Sommers, 1982) using Yanaco CN Corder Model MT-700 (Yanagimoto MFG. Co. Ltd., Kyoto, Japan).

Bulk density, total pore space, water holding capacity and $\mathrm{pH}$. Bulk density of a soil was calculated by using the sample in a $100 \mathrm{~cm}^{3}$-core. After oven dried at $105^{\circ} \mathrm{C}$ for about 72 hours, the weight of soil per core sample volume $\left(100 \mathrm{~cm}^{3}\right)$ was measured. Total pore 
space of soil determined gravimetrically by using the same sample for bulk density analyses. Water holding capacity (WHC) of soil sample conducted gravimetrically at field capacity condition. Soil $\mathrm{pH}$ was measured by using a glass electrode method with a soil: water ratio of 1:2.5 (w/v) (IITA, 1979; Mclean 1982), while biochar $\mathrm{pH}$ determined with ratio of 1:10 $(\mathrm{w} / \mathrm{v})$ (Jindo et al, 2014). The WHC of biochar calculated based on formula introduced by Yu et al, (2013).

\section{RESULTS AND DISCUSSION}

\section{General Properties of Soil and Biochar}

The soil properties at topsoil layer of study site characterized by slightly acid reaction ( $\mathrm{pH}$ 5.3), low organic matter content (15.22 $\mathrm{g} \mathrm{kg}^{-1}$ ) with fine texture (clay) and soil bulk density of $1.32 \mathrm{~g} \mathrm{~cm}^{-3}$. Total pore space of soil is $43 \%$ and water holding capacity $21 \%$, while soil permeability is slow $\left(2.3 \mathrm{~cm} \mathrm{hr}^{-1}\right)$. At subsoil layer, organic matter content found lower than topsoil $\left(8.62 \mathrm{~g} \mathrm{~kg}^{-1}\right)$, heavy clay, bulk density $1.39 \mathrm{~g} \mathrm{~cm}^{-3}$ with $22 \%$ water holding capacity, and soil permeability found slower $\left(1.8 \mathrm{~cm} \mathrm{hr}^{-1}\right)$.
Biochar found has alkaline reaction with $\mathrm{pH}$ of 8.1; low bulk density $\left(0.39 \mathrm{~g} \mathrm{~cm}^{-3}\right)$ and WHC of $648 \%(\mathrm{w} / \mathrm{w})$. Total carbon $(\mathrm{C})$ content of biochar was $473 \mathrm{~g} / \mathrm{kg}$ and total nitrogen $38 \mathrm{~g} / \mathrm{kg}$. This data indicated that the study site soil quality was decrease as compared with ideal soil. According to Brady and Weil (2003), the ideal soil has about $50 \mathrm{~g} \mathrm{~kg}^{-1}$ organic matter content with loamy textural class. The pore spaces of soil dominated by micro pore which retained water flow from soil surface into the deeper layer. Although total pore spaces in subsoil layer were higher than topsoil, the value of soil permeability at subsoil was lower.

\section{Effect of Biochar on Soil Quality}

Applications of biochar show enhance soil quality as a whole. The SOM content increased from $15.28 \mathrm{~g} \mathrm{~kg}^{-1}$ (without biochar) to $24.98,30.18,38.62$, 44.85 and $55.63 \mathrm{~g} \mathrm{~kg}^{-1}$ following addition of 2.5, 5.0, 7.5, 10.0 and $15.0 \mathrm{Mg} / \mathrm{ha}$ biochar, respectively (Figure 1). The correlation between treatment and SOM found very strong which indicated by high value of $\mathrm{R}^{2}$. Jindo et al, (2014) reported that organic carbon content of biochar made from non-wood materials ranges from $29-70 \%$.

Table 1. Basic properties of soil and biochar

\begin{tabular}{lll}
\hline Properties & Soil & Biochar \\
\hline $\mathrm{pH}$ & $5.3 \pm 0.8$ & $8.1 \pm 0.6$ \\
Total Carbon $\left(\mathrm{g} \mathrm{kg}^{-1}\right)$ & $8.85 \pm 1.24$ & $473.4 \pm 37.3$ \\
Total Nitrogen $\left(\mathrm{g} \mathrm{kg}^{-1}\right)$ & $1.79 \pm 0.06$ & $38 \pm 2.27$ \\
Bulk density $\left(\mathrm{g} \mathrm{cm}^{-3}\right)$ & $1.32 \pm 0.04$ & $0.39 \pm 0.06$ \\
Total Pore Space $(\%)$ & $43.62 \pm 3.22$ & - \\
WHC $(\%)$ & $21.3 \pm 2.19$ & $648.2 \pm 17.32$ \\
Texture class & Clay & - \\
\hline
\end{tabular}


The carbon content of biochar determined by original raw material and charring processes. Biochar that made by high temperature pyrolysis system resulted higher grade of biochar. Since the biochar used in this study made by an open-air pyrolysis, the temperature might not reach $500{ }^{\circ} \mathrm{C}$, which resulted in low carbon content of biochar.

Increasing in SOM content will create some advantage effect into the soil. Evidence from several laboratory and field studies suggests that the application of biochar may lead to decreased nutrient leaching (studies particularly focused on nitrates) and contaminant transport below the root zone. Several mechanisms contribute to the decrease in nutrient leaching which are related to increased nutrient use efficiency by increased water and nutrient retention (residence time in the root zone) and availability, related to an increased internal reactive surface area of the soil-biochar matrix, decreased water percolation below the root zone related to increased plant water use (increased evaporative surface), and increased plant nutrient use through enhanced crop growth. Higher retention times also permit a better decomposition of organic material and promote the breakdown of agrichemicals. Nevertheless, mechanisms such as colloid-facilitated transport of contaminants by biochar particles, or preferential flow induced by biochar applications, and long term stability of biochar in soil, are potential factors that my increase the leaching of nutrients and/or contaminants (Verheijen et al, 2010).

The trend changes of soil bulk density show appose as compared with soil organic matter content. Application of solid waste biochar found lowering soil bulk density in the study site. The value of soil bulk density decreased from $1.32 \mathrm{~g}$ $\mathrm{cm}^{-3}$ (without biochar) to $1.30,1.27,1.24$, 1.22 and $1.17 \mathrm{~g} \mathrm{~cm} \mathrm{~cm}^{-3}$, following application of 2.5, 5.0, 7.5, 10.0 and 15.0 $\mathrm{Mg} \mathrm{ha}^{-1}$ biochar, respectively.

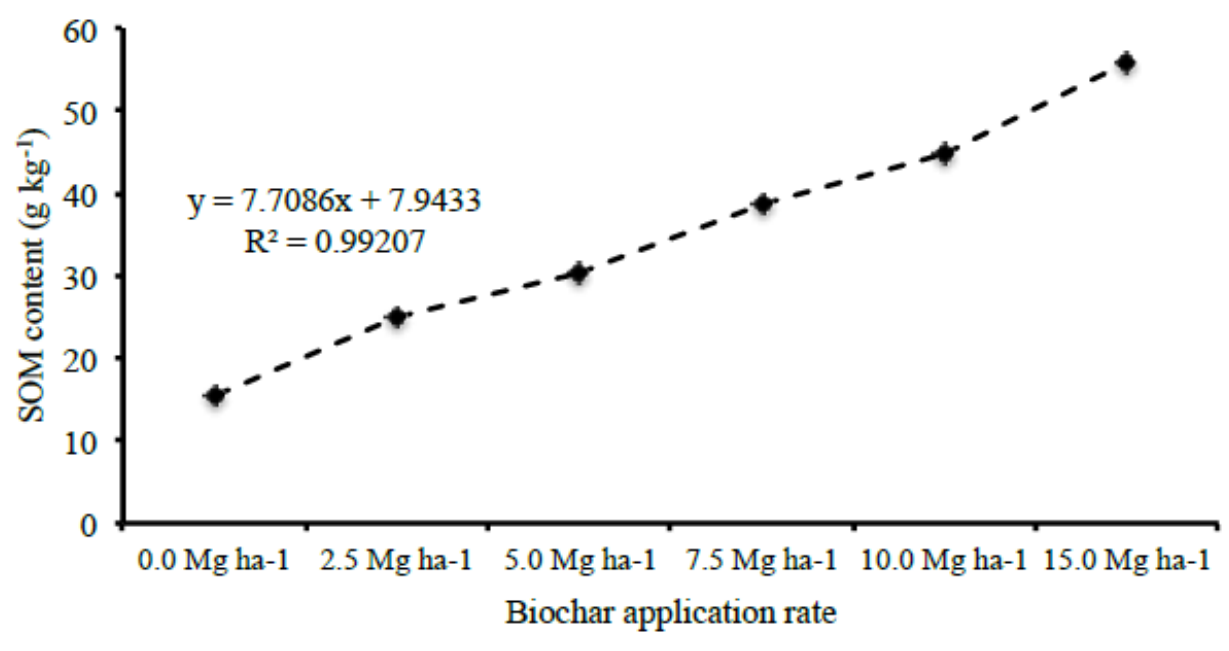

Figure 1. Effect of biochar application on soil organic matter content. 


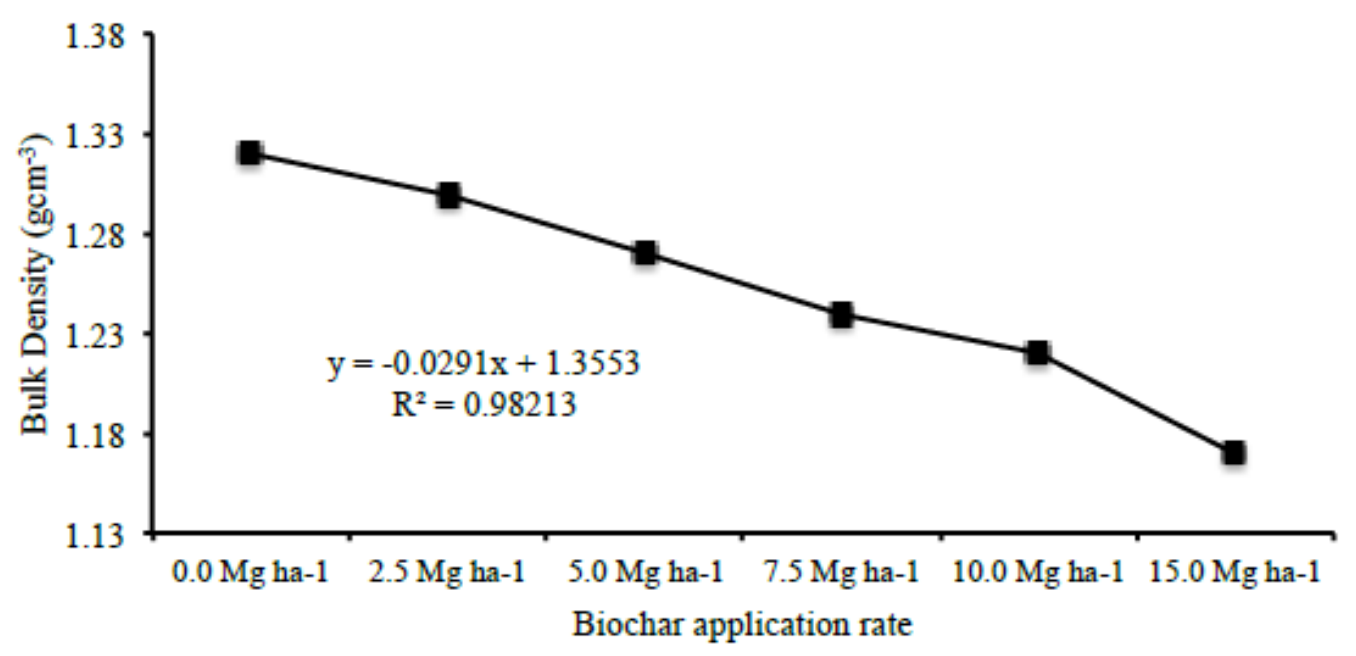

Figure 2. Effect of biochar application soil bulk density.

Biochar has a bulk density much lower than that of mineral soils and, therefore, application of biochar can reduce the overall bulk density of the soil, although increases in bulk density are also possible. If $100 \mathrm{t} \mathrm{ha}^{-1}$ of biochar with a bulk density of $0.4 \mathrm{~g} \mathrm{~cm}^{-3}$ is applied to the top $20 \mathrm{~cm}$ of a soil with a bulk density of $1.3 \mathrm{~g} \mathrm{~cm}^{-3}$, and the biochar particles do not fill up existing soil pore space, then the soil surface in that field will be raised by $c a .2 .5 \mathrm{~cm}$ with an overall bulk density reduction (assuming homogeneous mixing) of $0.1 \mathrm{~g} \mathrm{~cm}^{-3}$ to $1.2 \mathrm{~g} \mathrm{~cm}^{-3}$. However, if the biochar that is applied has a low mechanical strength and disintegrates relatively quickly into small particles that fill up existing pore spaces in the soil, and then the dry bulk density of the soil will increase. Since the average particle size of biochar used in this study more than $15 \mathrm{~mm}$, the possibility of clogging in soil pore space seemed not occur (Figure 2).

In agronomy, relatively small differences in soil bulk density can be associated with agronomic benefits.
Conventionally, i.e., without biochar additions, lower bulk density is associated with higher SOM content leading to nutrient release and retention (fertilizer saving) and/or lower soil compaction due to better soil management (potentially leading to improved seed germination and cost savings for tillage and cultivation). Biochar application to soil by itself may improve nutrient retention directly, but nutrient release is mostly very small (Verheijen et al, 2010).

Soil compatibility is closely related to soil bulk density. Soane (1990) reviewed the effect of SOM on compatibility and proposed several mechanisms by which SOM may influence the ability of the soil to resist compactify loads. First, binding forces between particles and within aggregates. Many of the long-chain molecules present in SOM are very effective in binding mineral particles. This is of great importance within aggregates, which are bound by a matrix of humic material and mucilage. 


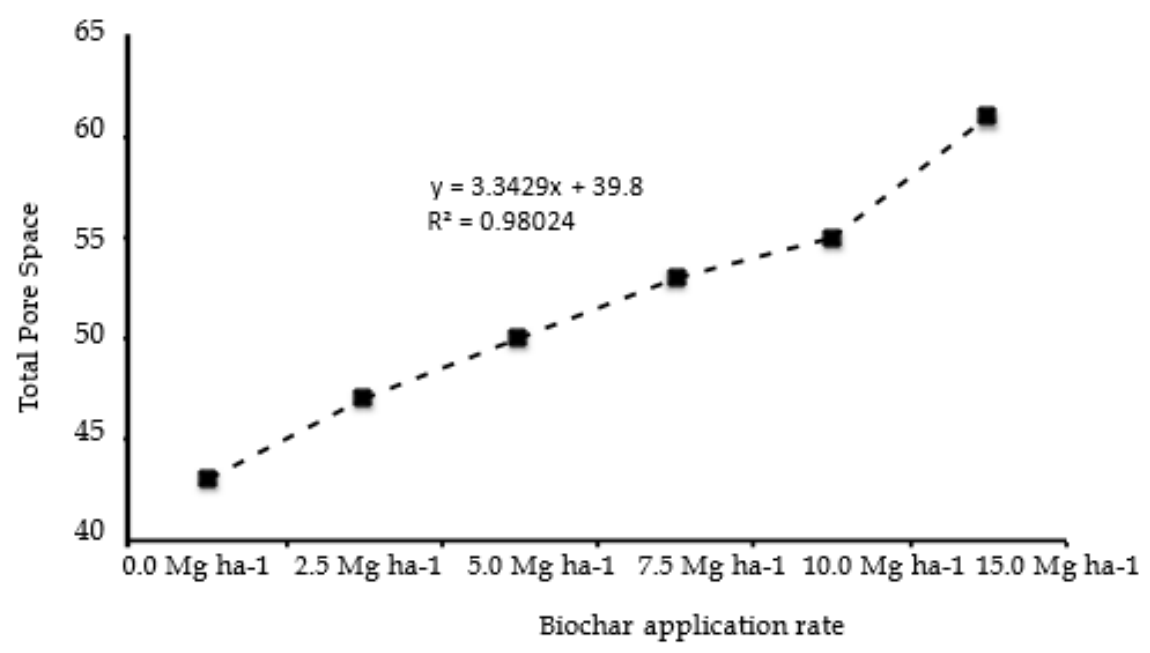

Figure 3. Effect of biochar application on total pore space of soils.

Addition of biochar increased total pore space (TPS) of soils (Figure 3). The increasing pattern of TPS found linear with the dose of biochar application. Enhancing TPS of soil might be because of the size of biochar used in this study is much bigger than mineral soil particles that can create more spaces between soil particle (Figure 4). Another reason is the ability of organic compounds may increase the hydraulic conductivity of clays by changing the electrical charge on the clay particles causing them to move closer together, flocculate and shrink, resulting in cracks and increased

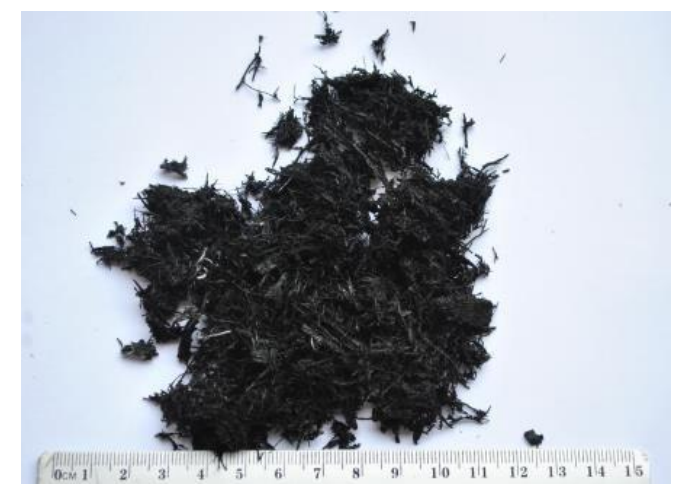

secondary macro-porosity of soil (Soane, 1990).

The soil pore network can be affected by biochar's inherent porosity as well as its other characteristics, in several ways. Biochar particle size and pore size distribution and connectivity, the mechanical strength of the biochar particles, and the translocation and interaction of biochar particles in the soil are all determining factors that will lead to different outcomes in different soilclimate-management combinations. These factors can cause the overall porosity of the soil to increase or decrease following biochar incorporation into soils.

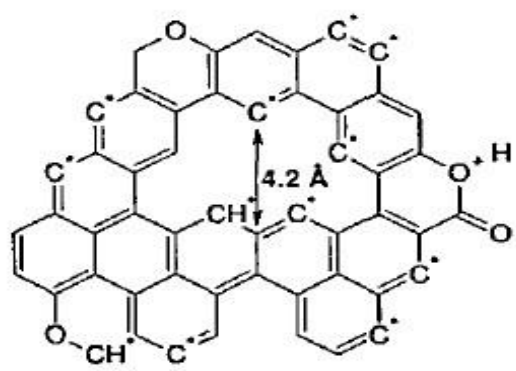

Figure 4. The size of biochar used in this study (left) and schematic of biochar structure (right) (Adopted from Bourke et al, 2007) 


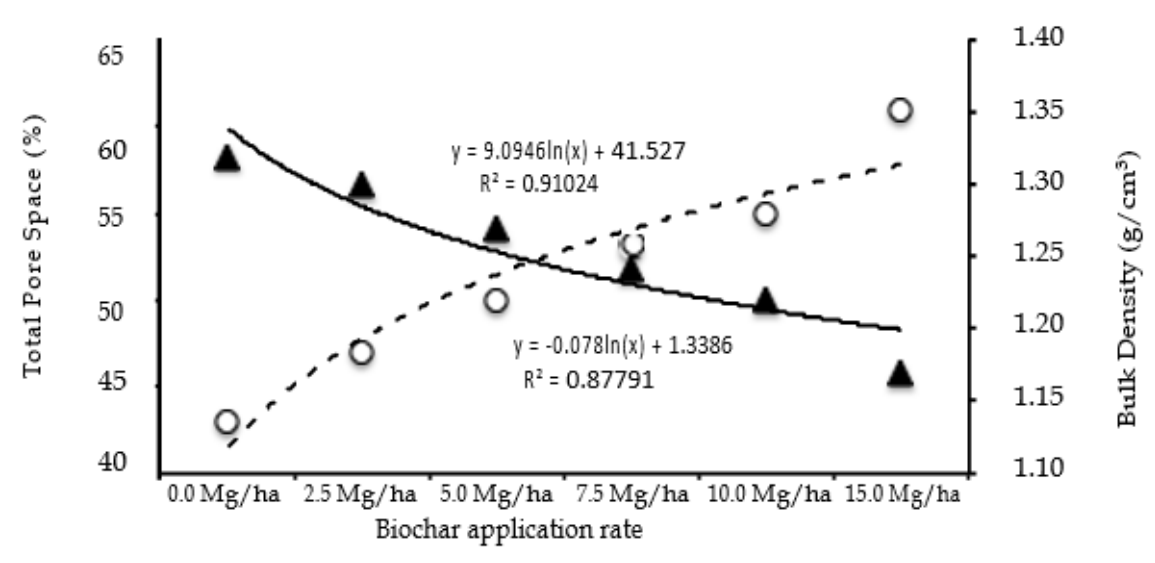

Figure 5. Effect of biochar addition on correlation pattern between soil bulk density and total pore space

Increasing of total pore space of soil show correlation with declining of soil bulk density (Figure 5). Declining of soil bulk density could be due to enlarging total pore space of soil. As presented in Figure 4, the biochar used in this study has bigger size as compare with mineral soil particle. On the other hand, the biochar structure also may possible to enhance the amount of soil macropores that responsible factor for increasing soil pore space.

Water holding capacity (WHC) of soil found increased significantly by biochar application. The WHC increased from $21 \%$ at initial condition to 24,29 , 35,40 and $43 \%$, following addition of 2.5 , 5.0, 7.5, 10.0 and $15.0 \mathrm{Mg} \mathrm{ha}^{-1}$ biochar, respectively. Improving the WHC of soil might be due to biochar used in this study has capability to hold water more than sixfold of its weight (Figure 5).

The mechanisms that lead to biochar provided potential improvements in water retention are relatively straightforward. Adding biochar to soil can have direct and indirect effects on soil water retention, which can be short or long lived. Water retention of soil is determined by the distribution and connectivity of pores in the soil- medium, which is largely regulated by soil particle size (texture), combined with structural characteristics (aggregation) and SOM content.

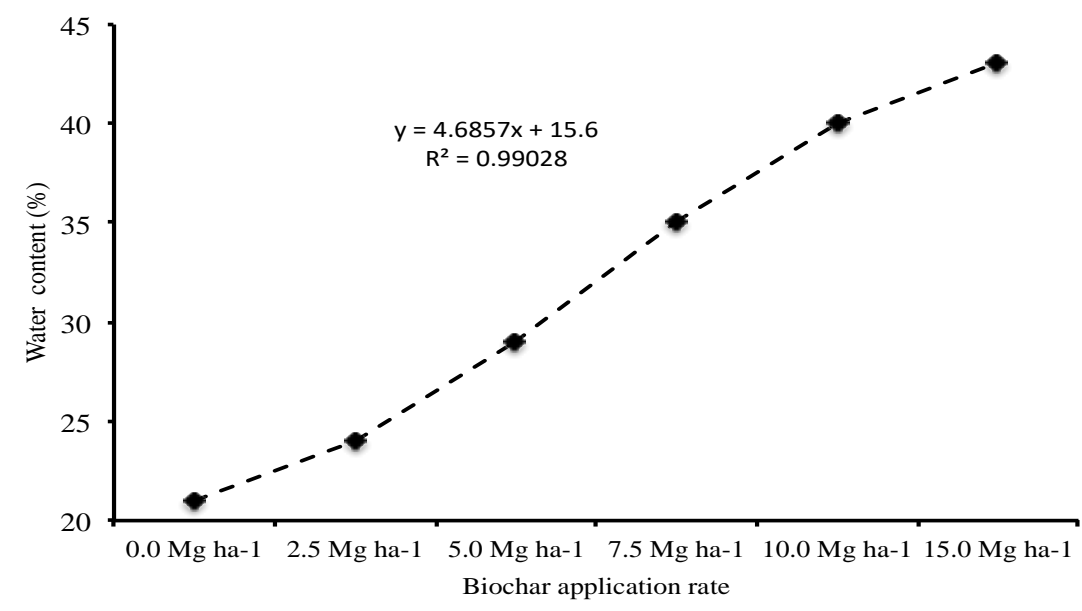

Figure 6. Effect of biochar application on water holding capacity of soils. 
The direct effect of biochar application is related to the large inner surface area of biochar. Biochar with a range in porous structures will result from feedstocks as variable as straw, wood and manure. Kishimoto and Sugiura (1985) estimated the inner surface area of charcoal formed between 400 and $1000{ }^{\circ} \mathrm{C}$ to range from 200 to $400 \mathrm{~m}^{2} \mathrm{~g}^{-1}$. Van Zwieten et al, (2009) measured the surface area of biochar derived from paper mill waste with slow pyrolysis at $115 \mathrm{~m}^{2} \mathrm{~g}^{-1}$.

Biochar's effects on water when mixed with soils are important to understand because it may be the most influential aspect of biochar in regards to microbial activity, plant growth, and nutrient usage. The current practices of irrigation are awaiting a revolution in order to more efficiently provide soils with water, but it will be important to understand the possible impact of preparing soils with amendments such as biochar. Biochar has high total porosity, and it can both retain water in small pores and thus increase WHC and let the water flow through the larger pores after heavy rain from topsoil to deeper soil layers (Asai et al, 2009).

The mechanical stability and recalcitrance of biochar once incorporated in the soil will determine long term effects on water retention and soil structure. This is determined by feedstock type and operating conditions as well as the prevalent physical-chemical conditions that determine its weathering and the compaction and compression of the biochar material in time. The effect of the use of heavy agricultural machinery on compaction of the soil-biochar matrix has yet to be studied in detail. Another factor contributing to the uncertainty in longterm beneficial effects of biochar application to soil is the potential clogging or cementation of soil pores with disintegrated biochar material (Brodowski et al, 2006).

Biochar's high surface area can thus lead to increased water retention, although the effect seems to depend on the initial texture of the soil. Therefore, improvements of soil water retention by charcoal additions may only be expected in coarse-textured soils or soils with large amounts of macropores. A draw-back is the large volume of biochar that needs to be added to the soil before it leads to increased water retention (Glaser et al, 2002).

\section{CONCLUSION}

Degradation of soil quality and huge amount of solid waste are the main problem of oil palm plantation. These problems can be solved by utilize the solid waste as organic matter sources. To avoid adverse effect of using decomposable organic matter, the solid waste can be change into biochar through pyrolysis process. This study proved that application of solid waste biochar could enhance soil quality that indicated by increasing soil organic matter (SOM) content. Improving SOM, affect other soil quality parameter such as decreasing of soil bulk density and augmenting of total pore space of soil. To examine the effect of enlightening of these soil characters on soil chemical characteristic and plant growth and productivity, long-term study is needed.

\section{ACKNOWLEDGEMENTS}

This study was supported by Ministry of Finance, Republic of Indonesia (Badan Pengelola Dana Perkebunan Kelapa Sawit) (PRJ45/DPKS/2015). We are thanked full to Ir. Huzriedi (Estate Manager of PT. Tidar Kerinci Agung) for gave us permission 
conducting this research. Our deep gratitude also goes to Mr. Sapuranda Siregar for various help during our fieldwork.

\section{REFERENCES}

Bourke, J., Manley-Harris, M., Fushimi, C., Dowaki, K., Nunoura, T., \& Antal, M. J. (2007). Do all carbonised charcols have the same structure? A model of the chemical structrue of carbonized charcoal. Industrial and Engineering Chemistry Research, 46, 5954-5967.

Brady, N.C., and Weil, R. R. (2002). The Nature and Properties of Soils, 10th ed, Macmillan New York., pp. 960.

Brodowski, S., John, B., Flessa, H. and Amelung, W., (2006). Aggregateoccluded black carbon in soil. European Journal of Soil Science 57(4), 539-546.

Corley, R. H. V., and Tinker, P.B.H. (2003). The Oil Palm, $4^{\text {th }}$ ed. Blackwell Science. Ltd

Edwards, R., Mulligan, D. and Marelli, L. (2010). Indirect land uses change from increased biofuels demand: Comparison of models and results for marginal biofuels production from different feedstock. Final Report. Luxemburg. European Commission Joint Research Centre - Institute for Energy.

Fowles, M. (2007). Black carbon sequestration as an alternative to bioenergy. Biomass

and

Bioenergy, 31(6), 426-432.

Germer, J. and Sauerborn, J. (2008). Estimation of the impact of oil palm plantation establishment on greenhouse gas balance. Environment, Development and Sustainability, 10 (6), 697-716

Glaser, B., Lehmann, J., Zech, W. (2002). Ameliorating physical and chemical properties of highly weathered soils in the tropics with charcoal: a review. Biology and Fertility of Soils, 35, 219-230.

IITA. (1979). Selected Methods for Soils and Plant Analysis, Manual Series No. 1, Ibadan Nigeria., pp. 70 .

Jindo. K, Mizumoto. H, Sawada. Y, Sanchez-Monedero. M.A and Sonoki. T. (2014). Physical and chemical characterization of biochar derived from different agricultural residues. Journal Biogeosciences. 11, 6613 - 6621.

Koh, L.P. and Ghazoul J. (2008). Biofuels, biodiversity, and people: Understanding the conflict and finding opportunities. Biological Conservation, 141, 2450-2460.

Lehmann, J. (2007). A handful of Carbon. Nature, 447, 143-144.

Lehmann, J., Gaunt, J. and Rondon, M. (2006). Bio-char sequestration in terrestrial ecosystems - A review. Mitigation and Adaptation Strategies for Global Change, 11(2), 403-427. 
McCarthy and John F. (2010). Processes of inclusion and adverse incorporation: oil palm and agrarian change in Sumatra, Indonesia. Journal of Peasant Studies, 37(4), 821- 850.

McLean, E. O. (1983). Soil pH and lime requirement. Methods of soil analysis: Part 2 Chemical and microbiological properties, 9, 199224.

Nelson, D. W., \& Sommers, L. (1983). Total carbon, organic carbon, and organic matter. Methods of soil analysis: Part 2 chemical and microbiological properties, 9, 539579.

Reeves, D.W. (1997). The role of soil organic matter in maintaining soil quality in continuous cropping system. Journal Soil and Tillage Research, 43, 131 - 167.

Soane, B. D., (1990). The Role of Organic-Matter in Soil Compactibility - a Review of Some Practical Aspects. Soil \& Tillage Research, 16, 179-201.

Tan, K.T., Lee K.T., Mohamed, A.R., Bhatia, S., (2009). Palm oil: Addressing issues and towards sustainable development.
Renewable and Sustainable Energy Reviews, 13, 420-427.

USDA (United States Department of Agriculture). (2012). Oil Seeds: World Market and Trade. Washington DC. Foreign Agricultural Services. Circular Series FOP 08-12, August 2012.

Van Zwieten, L., Kimber, S., Morris, S., Chan, K.Y., Downie, A., Rust, J., Joseph, S., and Cowie, A., (2009). Effects of biochar from slow pyrolysis of papermill waste on agronomic performance and soil fertility. Plant and Soil, 1-12.

Verheijen, F., Jeffery, S., Bastos, A. C., Van der Velde, M., \& Diafas, I. (2010). Biochar application to soils. A critical scientific review of effects on soil properties, processes, and functions. EUR, 24099, 162.

World Bank and IFC. (2011). The World Bank Group Framework and IFC Strategy for Engagement in the Palm Oil Sector.

Yu, O. Y., Raichle, B., \& Sink, S. (2013). Impact of biochar on the water holding capacity of loamy sand soil. International Journal of Energy and

Environmental

Engineering, 4(1), 1-9. 